Original Research Paper

\title{
Palm Oil Sludge Fermentation with Pleurotus ostreatus and its Application in Laying Quails' Ration
}

\author{
Ade Trisna, Nuraini, Yoze Rizal and Mirzah \\ Faculty of Animal Science, Andalas University Padang, Indonesia
}

Article history

Received: 29-03-2020

Revised: $17-06-2020$

Accepted: 08-12-2020

Corresponding Author:

Nuraini

Faculty of Animal Science

Andalas University Padang,

Indonesia

Email: nuraini@ansci.unand.ac.id

\begin{abstract}
Palm oil sludge is a byproduct of palm oil processing which is still limited in its use as a constituent of poultry feed. This study aims to improve the quality of palm sludge fermented with Pleurotus ostreatus and to determine its effect on the production of laying quail. The study was divided into 2 stages of research. Phase 1 of the laboratory experiment was the determination of the dose of the inoculum and the duration of fermentation of palm sludge. This stage uses a Completely Randomized Design (CRD) $3 \times 3$ treatment design with 3 replications. A Factor (inoculum dose) is ( $\mathrm{A} 1=6 \%, \mathrm{~A} 2=8 \%$ and $\mathrm{A} 3=10 \%$ ) of the number of substrates. B Factor (fermentation time) is (B1 = 9 days, B2 = 11 days and B3 = 13 days). The parameters measured were the activity of cellulase enzymes $(\mathrm{U} / \mathrm{ml})$, lignin peroxidase $(\mathrm{U} / \mathrm{ml})$ and crude fiber content $(\%)$, cellulose $(\%)$ and lignin $(\%)$. Phase 2 biological experiment to laying quails is the application of Fermented Palm Sludge (FPS) products in laying quail rations. This stage uses a Completely Randomized Design (CRD) with 5 treatments and 4 replications. Provision of FPS consisting of: A (0\% FPS), B (6\% FPS), C (12\% FPS), D $(18 \%$ FPS $)$, E (24\% FPS). The parameters measured were feed consumption (g/head/day) and daily egg production (\%). The results of the Phase 1 variance analysis showed that there was no interaction $(\mathrm{P}>0.05)$ between the inoculum dose and the fermentation time for the activity of cellulase enzymes, lignin peroxidase $(\mathrm{U} / \mathrm{ml})$ and the content of crude fiber, cellulose and lignin fermented palm sludge, but inoculum doses highly significant effect $(\mathrm{P}<0.01)$ on the activity of cellulase $(\mathrm{U} / \mathrm{ml})$, lignin peroxidase $(\mathrm{U} / \mathrm{ml})$, crude fiber content $(\%)$, cellulose $(\%)$ and lignin (\%). The results of the Phase 2 variance analysis showed that the use of FPS with Pleurotus ostreatus had no significant effect $(\mathrm{P}>0.05)$ on ration consumption and egg production. The results of the study concluded that the $8 \%$ inoculum dose and 9 days fermentation time was the best treatments to improve the quality of palm sludge. FPS can be used up to $24 \%$ in laying quail rations. At this level, it can reduce $27.30 \%$ corn and $55.02 \%$ soybean meal and can maintain the same ration consumption and egg production as control.
\end{abstract}

Keywords: Dose of Inoculum, Duration of Fermentation, Pleurotus Ostreatus, Palm Sludge, Laying Quails and Cellulase Enzymes

\section{Introduction}

The existence of poultry is very important because it contributes to providing animal protein. One bird whose eggs can be used as animal protein in a large quantity is quail. Quail egg production in one year ranges from 200300 eggs (Amo et al., 2013). According to data from the
Director-General of Animal Husbandry and Animal Health, quail population in Indonesia is estimated to $14,570,000$ heads. Increasing the quail population requires the availability of sufficient food for the main needs such as basic living, growth, production and reproduction for birds. Conventional feed is relatively expensive and in animal husbandry business, the cost of 
feed is the largest production cost (60-70\%) that must be spent by farmers/ranchers (Amrullah, 2004). But the effort to provide continuous feed is increasingly difficult because the price of feed is expensive and still depends on conventional or commercial feed so that alternative feed (unconventional) is needed which is of good nutritional content, available in large quantities, continuous and inexpensive.

Unconventional feed resources that can be used as animal feed are agricultural waste or agricultural industrial waste. The agricultural industry is constantly increasing especially the palm oil processing industry, which produces waste called palm sludge. Indonesian plantation statistics data released in 2014 by the directorate general of plantations reported that the total area of oil palm plantations in Indonesia in 2013 reached $10,465,020 \mathrm{Ha}$. In 2014 the area of oil palm plantations continued to increase reaching $10,754,801 \mathrm{Ha}$ and in 2015 the area of oil palm plantations was estimated to reach 11,300,370 Ha DGIP, 2015. For every ton of palm oil yields, around 2-3 tons of palm sludge are produced (Fauzi et al., 2012).

Palm sludge has crude protein content $(11.35 \%)$, crude fiber $(25.80 \%)$, cellulose $(16.15 \%)$, lignin $(19.19 \%)$ and metabolic energy of $1550 \mathrm{kcal} / \mathrm{kg}$ (Nuraini and Trisna, 2017). In poultry, especially broiler oil palm sludge ranges from 5\% (Sinurat et al., 2001), because the increasing content of crude fiber contained in palm sludge in the ration can cause a decrease in chicken performance which can reduce feed consumption and slower growth (Sinurat, 2003). Therefore, to use oil palm sludge, efforts should be made to reduce the limiting factors and improve the quality of oil palm sludge. One way to solve this problem is by palm sludge fermentation to increase nutrient content and reduce the levels of crude fiber sludge. Fermentation biotechnology approach can be used to overcome high crude fiber in palm sludge by utilizing the role of microorganisms. The use of fermented palm sludge with Lentinus edodes as a constituent of quail rations can be used up to $20 \%$ in rations (Nuraini and Trisna, 2017). Other fungi derived from the Basidiomycete groups, which are also effective in degrading high lignocellulosic materials are white-rot fungi known as lignocellulolytic fungi, one of which is Pleurotus ostreatus (Hatakka, 2001; Sun and Cheng, 2002).

Nuraini and Mahata (2015) states that the success of a solid media fermentation highly depends on the optimum conditions given such as the composition of the substrate, thickness of the substrate, the dose of the inoculum and the length of fermentation. The use of fermented palm sludge with Pleurotus ostreatus against laying quail is unknown. Based on the description above, a study was conducted to determine the best dosage of inoculum and fermentation time with Pleurotus ostreatus and test the effect on quail egg production performance.

\section{Materials and Methods}

\section{Stage 1. Determination of the Best Inoculum Dosage and Fermentation Time of Palm Sludge Fermented with Pleurotus ostreatus}

\section{Palm Oil Sludge Fermentation}

The substrate consisting of $90 \%$ palm sludge and $10 \%$ bran, added to heat-resistant plastic is added with distilled water and Brook solution (60\% water content) then homogenized. The substrate is sterilized with an autoclave at $121^{\circ} \mathrm{C}$ for $15 \mathrm{~min}$. Leave it until the temperature drops to room temperature $25-30^{\circ} \mathrm{C}$. After that, the substrate was inoculated with Pleurotus ostreatus (6, 8 and 10\%) of the total substrate. Then stir evenly and incubated according to the treatment for $(9,11$ and 13 days) in a glass bottle and covered with gauze. The fermentation product is dried in an oven at $80^{\circ} \mathrm{C}$ for $2 \mathrm{~h}$ to kill the fungus and continued drying at $60^{\circ} \mathrm{C}$ for $10 \mathrm{~h}$. The product is stirred evenly and ready to be analyzed.

\section{Enzymatic Activity}

5 grams of enzyme and soaked with $50 \mathrm{~mL}$ of $0.05 \mathrm{M}$ $\mathrm{Ph} 5$ acetate buffer, then let stand for $2 \mathrm{~h}$, strain and take the filtrate. The filtrate is centrifuged $15000 \mathrm{rpm}$ for 15 min, then a crude enzyme was extracted. Laccase enzyme activity was measured based on the study of (Buswell et al., 1995). The sample solution was prepared with a $0.4 \mathrm{~mL}$ enzyme filtrate mixed with $0.5 \mathrm{~mL}$ acetate buffer $0.5 \mathrm{M} \mathrm{Ph} 5$ and $0.1 \mathrm{~mL}$ ABTS $1 \mathrm{Mm}$. This mixture was put into a cuvette and then shaken. After shaking, the solution was measured at a wavelength of $420 \mathrm{~nm}$ with time intervals of 0 and $30 \mathrm{~min}$. Lignin Peroxidase enzyme activity (LiP) was measured based on the method of (Tien and Kirk, 1984). $0.2 \mathrm{~mL}$ of filtrated enzyme, $0.5 \mathrm{~mL}$ of 5 $\mathrm{mM} \mathrm{H}_{2} \mathrm{O}_{2}, 0.1 \mathrm{~mL}$ of $8 \mathrm{mM}$ vetratril alcohol, $0.2 \mathrm{~mL}$ of $0.05 \mathrm{M}$ acetate buffer $\mathrm{pH} 3$ and $0.45 \mathrm{~mL}$ of distilled water were added to the cuvette and shaken. The solution was read absorbance at a wavelength of $310 \mathrm{~nm}$ with a 0 and 30 min time interval.

\section{Experimental Design}

This research was conducted by an experimental method with a Completely Randomized Design (CRD) factorial pattern $3 \times 3$ with 3 replications. Factor $\mathrm{A}$ (inoculum dose) is $(\mathrm{A} 1=6 \%, \mathrm{~A} 2=8 \%$ and $\mathrm{A} 3=10 \%$ ) of the number of substrates. Factor $\mathrm{B}$ (fermentation time) is $(\mathrm{B} 1=9$ days, $\mathrm{B} 2=11$ days and $\mathrm{B} 3=13$ days $)$.

\section{Variables}

The parameters measured were cellulase enzyme activity $(\mathrm{U} / \mathrm{ml})$, lignin peroxidase enzyme activity $(\mathrm{U} / \mathrm{ml})$, crude fiber content $(\%)$, cellulose content $(\%)$ and lignin content $(\%)$. 


\section{Data Analysis}

Statistical analysis data with the analysis of variance based on a Completely Randomized Design (CRD) factorial pattern $3 \times 3$ with 3 replications in Table 2 . Differences between treatments were tested by Duncan's Multiple Range Test (DMRT).

Stage 2. Application of Fermented Palm Sludge (FPS) Products with Pleurotus ostreatus in Laying Quail Rations

\section{Palm Sludge Fermentation with Pleurotus ostreatus}

The substrate used is $500 \mathrm{~g}$, consisting of $90 \%$ palm oil $(450 \mathrm{~g})$ and $10 \%$ bran $(50 \mathrm{~g})$, then adding distilled water and Brook solution (60\% water content). The material is sterilized in an autoclave (temperature of $121^{\circ} \mathrm{C}$ for $15 \mathrm{~min}$ ), then inoculated with $8 \%$ Pleurotus ostreatus inoculum, stirred evenly and flattened to a thickness of $1 \mathrm{~cm}$ and incubated for 9 days.

\section{Experimental Design}

Rations were prepared with a content of $20 \%$ crude protein and $2800 \mathrm{kcal} / \mathrm{kg}$ metabolic energy. This research was conducted using an experimental method designed with a Completely Randomized Design (CRD) method with 5 treatments and 4 replications, each consisting of 10 quails as a unit of the experiment. Provision of FPS consisting of: A (0\% FPS), B (6\% FPS), C (12\% FPS), D (18\% FPS), E (24\% FPS). Feed ingredients, the content of food substances and metabolic energy of the ingredients of ration (as feed) can be seen from Table 1 . While the composition of rations, food content and energy of research rations can be seen in Table 2. The ration was prepared with isoprotein $(20 \%)$ and isoenergy $(2800 \mathrm{kcal} / \mathrm{kg}$ ) according to (Djulardi, 1995).

\section{Birds}

The birds used in this study are 200 quails (Coturnixcoturnix japonica) of the 20 -week laying phase.

Table 1: The content of food substances (\%), metabolic energy ( $\mathrm{kcal} / \mathrm{kg}$ ) and ration ingredients (as feed)

\begin{tabular}{lllllllll}
\hline Feed ingredients & Crude pretein & Fat & Rough fiber & Ca & P & ME (kkal) & Metionin & Lysin \\
\hline Corn & 8,20 & 2,66 & 2,90 & 0,38 & 0,19 & 3300,00 & 0,18 & 0,26 \\
Consentrate 126 & 38,00 & 4,00 & 8,00 & 5,50 & 1,00 & 2910,00 & 1,00 & 1,76 \\
Soybean & 45,35 & 2,49 & 7,50 & 0,63 & 0,36 & 2240,00 & 0,50 & 0,60 \\
Coconut Oil & 0,00 & 100,00 & 0,00 & 0,00 & 0,00 & 8600,00 & 0,0 & 0,00 \\
FPM & 21,87 & 3,12 & 14,21 & 0,24 & 0,29 & 2107,47 & $0,55^{\mathrm{a}}$ & $1,14^{\mathrm{a}}$ \\
Flour & 0,00 & 0,00 & 0,00 & 24,00 & 12,00 & 0,00 & 0,00 & 0,00 \\
Lysin & & & & & & & & 99,00 \\
CaCO3 & & & & 40,00 & & & 0,30 & 0,30 \\
Top mix & & & & 5,38 & 1,44 & & 0,27 & 0,67 \\
Dedak & 9,28 & 4,09 & 16,02 & 0,69 & 0,26 & 1640 & 0,26 \\
\hline
\end{tabular}

Table 2: Ration composition (\%), food content (\%) and metabolic energy (kcal/kg) of research ration

\begin{tabular}{|c|c|c|c|c|c|}
\hline \multirow[b]{2}{*}{ Feed ingredients } & \multicolumn{5}{|c|}{ Composition of treatment ration } \\
\hline & A & $\mathrm{B}$ & $\mathrm{C}$ & $\mathrm{D}$ & $\mathrm{E}$ \\
\hline Corn & 50,55 & 47,75 & 44,00 & 40,45 & 36,75 \\
\hline Concentrate 126 & 23,75 & 23,75 & 23,75 & 23,75 & 23,75 \\
\hline Soybean meal & 14,45 & 12,65 & 10,55 & 8,45 & 6,50 \\
\hline Coconut oil & 0,50 & 1,00 & 1,85 & 2,50 & 3,00 \\
\hline Fermented palm sludge & 0,00 & 6,00 & 12,00 & 18,00 & 24,00 \\
\hline Flour & 4,00 & 4,15 & 4,15 & 4,20 & 4,40 \\
\hline Lisin sintesis & 0,25 & 0,20 & 0,20 & 0,15 & 0,10 \\
\hline $\mathrm{CaCO}_{3}$ & 1,00 & 1,00 & 1,00 & 1,00 & 1,00 \\
\hline Top Mix & 0,50 & 0,50 & 0,50 & 0,50 & 0,50 \\
\hline Bran & 5,00 & 3,00 & 2,00 & 1,00 & 0,00 \\
\hline Total & 100,00 & 100,00 & 100,00 & 100,00 & 100,00 \\
\hline Protein & 20,19 & 20,27 & 20,23 & 20,20 & 20,24 \\
\hline Fat & 3,36 & 3,84 & 4,69 & 5,34 & 5,84 \\
\hline SK & 5,25 & 5,57 & 5,99 & 6,42 & 6,86 \\
\hline $\mathrm{Ca}$ & 3,01 & 3,03 & 3,01 & 3,00 & 3,03 \\
\hline Available P & 0,89 & 0,90 & 0,90 & 0,91 & 0,94 \\
\hline $\mathrm{ME}$ & 2807,96 & 2811,88 & 2824,24 & 2826,00 & 2813,27 \\
\hline Metionin & 0,42 & 0,43 & 0,44 & 0,46 & 0,47 \\
\hline Lisin & 0,92 & 0,91 & 0,95 & 0,94 & 0,93 \\
\hline
\end{tabular}




\section{Variables}

The parameters observed were feed consumption $(\mathrm{g} / \mathrm{head} / \mathrm{day})$ and daily egg production (\%).

\section{Data Analysis}

The data obtained are processed statistically by analysis of diversity according to (Steel and Torrie, 1995). Differences between treatments were tested with Duncan's Multiple Range Test (DMRT).

\section{Results}

Stage 1. Determination of the Best Inoculum Dosage and Fermentation Time of Palm Sludge Fermented with Pleurotus ostreatus

\section{a. Effect of Treatment on Cellulase Enzymes and} Lignin Peroxidase Activity

The effect of inoculum dose treatment and fermentation time on the average activity of cellulase $(\mathrm{U} / \mathrm{ml})$ enzyme and lignin peroxidase $(\mathrm{U} / \mathrm{ml})$ is presented in Table 3 . The results of the diversity analysis showed that there was no interaction $(\mathrm{P}>0.05)$ between A factor (dose of inoculum) with B factor (fermentation time) on cellulase enzyme activity and lignin peroxidase enzyme activity from palm sludge fermented with the fungus Pleurotus ostreatus. The dose of inoculum has different effects $(\mathrm{P}<0.01)$ on the activity of cellulase enzymes and lignin peroxidase enzymes.

\section{b. Effect of Treatment on Crude Fiber Content, Cellulose and Lignin}

The effect of inoculum dosage treatment and fermentation time on crude fiber content, cellulose and lignin are presented in Table 4 . The results of the diversity analysis showed that there was no interaction $(\mathrm{P}>0.05)$ between factor A (inoculum dose) and factor B (fermentation time) to crude fiber, cellulose and lignin content from palm sludge fermented with the fungus Pleurotus ostreatus. The dose of inoculum had a very significant effect $(\mathrm{P}<0.01)$ on the content of crude fiber, cellulose and lignin.

\section{Effect of FPS Fermented with Pleurotus ostreatus in the Ration on the Performance of Quail Egg Production}

Effect of treatment on feed consumption and quail egg production using fermented palm sludge with Pleurotus ostreatus in the ration can be seen in Table 5. The results of the diversity analysis show that the use of fermented palm sludge with Pleurotus ostreatus has no significant effect $(\mathrm{P}>0.05)$ on ration consumption and egg production.

Table 3: Cellulase $(\mathrm{U} / \mathrm{ml})$ and lignin peroxidase $(\mathrm{U} / \mathrm{ml})$ enzyme activities

\begin{tabular}{|c|c|c|c|c|c|}
\hline \multirow[b]{2}{*}{ Variable } & \multirow{2}{*}{$\begin{array}{l}\text { A factor } \\
\text { (Inoculum dose) }\end{array}$} & \multicolumn{3}{|c|}{ B Factor (Duration of fermentation) } & \multirow[b]{2}{*}{ Average } \\
\hline & & B1 (9 days) & B2 (11 days) & B3 (13 days) & \\
\hline \multirow[t]{4}{*}{ Cellulase (U/ml) } & A1 $(6 \%)$ & 3,79 & 3,81 & 3,82 & $3,81^{\mathrm{a}}$ \\
\hline & A2 $(8 \%)$ & 3,94 & 3,96 & 3,97 & $3,96^{\mathrm{b}}$ \\
\hline & A3 $(10 \%)$ & 3,96 & 3,98 & 3,98 & $3,98^{b}$ \\
\hline & Average & 3,90 & 3,92 & 3,93 & \\
\hline \multirow[t]{4}{*}{ Lignin Peroxidase (U/ml) } & A1 $(6 \%)$ & 38,03 & 38,23 & 38,53 & $38,26^{\mathrm{a}}$ \\
\hline & A2 $(8 \%)$ & 41,92 & 42,11 & 42,31 & $42,11^{\mathrm{b}}$ \\
\hline & A3 $(10 \%)$ & 42,02 & 42,21 & 42,51 & $42,25^{\mathrm{b}}$ \\
\hline & Average & 40,65 & 40,85 & 41,12 & \\
\hline
\end{tabular}

Note: Different superscripts in the same column show very significant different effects $(\mathrm{P}<0.01)$

Table 4: Content of crude fiber (\%), Cellulose (\%) and Lignin (\%)

\begin{tabular}{|c|c|c|c|c|c|}
\hline \multirow[b]{2}{*}{ Variable } & \multirow{2}{*}{$\begin{array}{l}\text { A Factor } \\
\text { (inoculum dose) }\end{array}$} & \multicolumn{3}{|c|}{ B Factor (Duration of fermentation) } & \multirow[b]{2}{*}{ Average } \\
\hline & & B1(9 days) & B2(11days) & B3(13days) & \\
\hline \multirow[t]{4}{*}{ Rough Fiber } & A1 $(6 \%)$ & 19,85 & 20,32 & 20,66 & $20,27^{\mathrm{a}}$ \\
\hline & $\mathrm{A} 2(8 \%)$ & 15,95 & 16,44 & 16,72 & $16,37^{\mathrm{b}}$ \\
\hline & A3 $(10 \%)$ & 14,87 & 15,75 & 15,81 & $15,48^{\mathrm{b}}$ \\
\hline & Average & 16,89 & 17,50 & 17,73 & \\
\hline \multirow[t]{4}{*}{ Cellulose } & A1 $(6 \%)$ & 14,03 & 14,19 & 14,37 & $14,20^{\mathrm{a}}$ \\
\hline & A2 $(8 \%)$ & 10,98 & 11,69 & 11,97 & $11,55^{\mathrm{b}}$ \\
\hline & A3 $(10 \%)$ & 10,13 & 11,55 & 11,91 & $11,20^{\mathrm{b}}$ \\
\hline & Average & 12,72 & 12,48 & 12,75 & \\
\hline \multirow[t]{4}{*}{ Lignin } & A1 $(6 \%)$ & 13,04 & 13,23 & 13,49 & $13,25^{\mathrm{a}}$ \\
\hline & $\mathrm{A} 2(8 \%)$ & 10,55 & 10,61 & 10,88 & $10,68^{\mathrm{b}}$ \\
\hline & A3 (10\%) & 9,99 & 10,45 & 10,72 & $10,39^{\mathrm{b}}$ \\
\hline & Average & 11,20 & 11,43 & 11,70 & \\
\hline
\end{tabular}

Note: Different superscripts in the same column show very significant different effects $(\mathrm{P}<0.01)$. 
Table 5: Consumption of ration ( $\mathrm{g} / \mathrm{head} / \mathrm{day})$ and egg production $(\%)$

\begin{tabular}{|c|c|c|}
\hline Treatment & $\begin{array}{l}\text { Ration consumption } \\
\text { (g/head/day) }\end{array}$ & $\begin{array}{l}\text { Egg production } \\
(\%)\end{array}$ \\
\hline $\mathrm{A}(0 \% \mathrm{FPM})$ & 22.76 & 80.00 \\
\hline $\mathrm{B}(6 \% \mathrm{FPM})$ & 22.71 & 79.91 \\
\hline $\mathrm{C}(12 \% \mathrm{FPM})$ & 22.74 & 79.73 \\
\hline $\mathrm{D}(18 \% \mathrm{FPM})$ & 22.76 & 79.55 \\
\hline E (24\% FPM) & 22.77 & 79.64 \\
\hline SE & 0.02 & 0.67 \\
\hline
\end{tabular}

Note: $\mathrm{FPM}=$ Fermented Palm Sludge

\section{Discussion}

Fermented palm sludge with the fungus Pleurotus ostreatus has an average cellulase enzyme activity between 3.79 to $3.98 \mathrm{U} / \mathrm{ml}$ and lignin peroxidase enzyme activity ranging from 38.03 to $42.51 \mathrm{U} / \mathrm{ml}$. The highest cellulase enzyme activity and lignin peroxidase enzyme activity were in the treatment of A2 and A3 by showing the same effect between the two. The length of fermentation has no significant effect $(\mathrm{P}>0.05)$ on cellulase enzyme and lignin peroxidase enzyme activities.

The influence of factor B (fermentation time) on the activity of cellulase and lignin peroxidase enzymes due to the fungus Pleurotus ostreatus on days 9 to 13 is still in the exponential phase so that the growth of the fungus Pleurotus ostreatus is fertile and evenly distributed. While factor A (inoculum dose) gives a significant effect between treatments because the more the dose increases the more fertile the fungus Pleurotus ostreatus and causes increased enzyme activity. The higher the doses of inoculum, the faster the fermentation process because with a high dose of inoculum causes the growth of microbes on the substrate more and more and the enzyme activity also increases. Inoculum dose and fermentation time work together to increase the activity of enzyme activity (Noferdiman and Yani, 2013).

The cellulase enzyme activity of Pleurotus ostreatus obtained from the results of this study was slightly lower (3.79 to $3.98 \mathrm{U} / \mathrm{ml}$ ) than the enzyme activity rate reported by (Daba et al., 2011) which was $4 \mathrm{U} / \mathrm{ml}$ on the 8th day of fermentation. While the activity of the Lignin Peroxidase enzymes (LiP) obtained from this study is also still below ( 38.03 to $42.51 \mathrm{U} / \mathrm{ml}$ ) of the enzyme activity reported by (Bilal and Asgher, 2016) that is equal to 45, $2 \mathrm{U} / \mathrm{ml}$ on the 10th day of fermentation on rice straw substrate.

The best average of cellulase enzyme activity and lignin peroxidase enzyme activity based on the efficiency of the inoculum dose and the fermentation time is in the same treatment, namely the A2B1 treatment $(8 \%$ inoculum dose and 9 days fermentation time) of $3.94 \mathrm{U} / \mathrm{ml}$ (cellulase enzyme activity) and 41.92 $\mathrm{U} / \mathrm{ml}$ (lignin peroxidase enzyme activity).

Fermented palm sludge with the fungus Pleurotus ostreatus has an average crude fiber content of 3.79 to $3.98 \mathrm{U} / \mathrm{ml}$ and the activity of the lignin peroxidase enzyme ranges from 38.03 to $42.51 \mathrm{U} / \mathrm{ml}$. The highest cellulase enzyme activity and lignin peroxidase enzyme activity were in the treatment of A 2 and A 3 by showing the same effect between the two. The length of fermentation has no significant effect $(\mathrm{P}>0.05)$ on crude fiber content, cellulose content and lignin content.

The low content of crude fiber, cellulose and lignin as a whole in A2 and A3 treatments is due to the activity of cellulase enzymes which are also high in A2 and A3 treatments so that they can break down the contents of crude fiber, cellulose and lignin. The low lignin content in A2 and A3 treatments was also proven by the high lignin peroxidase enzyme activity in A2 and A3 doses so that it was able to degrade lignin and to lower the lignin content. The research report (Noferdiman and Yani, 2013) explained that the addition of higher doses caused the fungus to grow more so that it increased the activity of cellulase and lignin peroxidase enzymes in degrading palm sludge. Extracellular enzymes produced by fungi degrade crude fiber cell wall components (Chesson, 1993). The fungus Pleurotus ostreatus contains lignin peroxidase and endocellulase enzymes (Chang and Chui, 1992). Pleurotus Ostreatus produces lignin peroxidase enzymes, manganese peroxidase and laccase (Howard et al., 2003; Kirk and Farrell, 1987) which can hydrolyze lignin, cellulose and hemicellulose into simpler components.

The best reduction of crude fiber, cellulose and lignin content based on the efficiency of the inoculum dose and the length of fermentation is in the treatment of A2B1 ( $8 \%$ inoculum dose and 9 days fermentation time). The treatment obtained crude fiber content (15.95\%), cellulose content (10.98\%) and lignin content (10.55\%).

Consumption of quail ration gives a significantly different result by giving FPS up to the level of $24 \%$ in the ration. This shows that FPS is favored by quail, although at that level the use of corn is reduced by $27.30 \%$ and soybean meal is reduced by $55.02 \%$. According to (Haddadin et al., 1996), the amount of feed consumed by birds is affected by palatability. Fermented products can produce flavors that are preferred by birds and have several vitamins (B1, B2, B12) so that birds are preferred compared to the original ingredients (Murugesan et al., 2005).

The effect of the treatment on daily egg production from treatment A to treatment E gave no significantly different results. This is caused by the consumption of rations that are also the same in each treatment. The same consumption shows that the amount of nutrients contained in the ration for egg formation is also the same, so egg production is also the same. The difference in egg production is also caused by protein consumption is also the same in every treatment. Protein consumption in treatment A to treatment E ranged from 4.59 to $4.61 \%$. Egg production is influenced by ration consumption, especially protein consumption (Rasyaf, 1992). 


\section{Conclusion}

Inoculum dose A2 (8\%) and B1 fermentation time (9 days) from Pleurotus ostreatus in palm sludge are the best treatment to improve the quality of palm sludge. In this condition cellulase enzyme activity $(3.94 \mathrm{U} / \mathrm{ml})$, lignin peroxidase enzyme activity $(41.92 \mathrm{U} / \mathrm{ml})$, crude fiber content $(15.95 \%)$, cellulose content $(10.98 \%)$ and lignin content $(10.55 \%)$ as showed in Table 3. Fermentation of palm sludge with Pleurotus ostreatus can be used as much as $24 \%$ in laying quail rations. In this condition, the consumption of $22.56 \mathrm{~g} / \mathrm{head} / \mathrm{day}$ was obtained and $80 \%$ of egg production was obtained daily.

\section{Authors' Contributions}

All the authors equally contributed to this study.

\section{Ethics}

This research has been approved by the Committee of Research Ethics of the Faculty of Animal Science of Andalas University Padang, Indonesia and therefore, no ethical issues may arise after its publication.

\section{References}

Amo, L., Jansen, J. J., van Dam, N. M., Dicke, M., \& Visser, M. E. (2013). Birds exploit herbivore-induced plant volatiles to locate herbivorous prey. Ecology letters, 16(11), 1348-1355.

Amrullah, I. K. (2004). Nutrisi Ayam Petelur. Cetakan $\mathrm{Ke}-3$.

Bilal, M., \& Asgher, M. (2016). Biodegradation of agrowastes by lignocellulolytic activity of an oyster mushroom, Pleurotus sapidus. Journal of the National Science Foundation of Sri Lanka, 44(4).

Buswell, J. A., Cai, Y., \& Chang, S. T. (1995). Effect of nutrient nitrogen and manganese on manganese peroxidase and laccase production by Lentinula (Lentinus) edodes. FEMS microbiology letters, 128(1), 81-87.

Chesson, A. (1993). Feed enzymes. Animal feed science and technology, 45(1), 65-79.

Chang, S. T., \& Chiu, S. W. (1992). Mushroom productionAn economic measure in maintenance of food security. Microbial Technology: Economic and Social Aspects, Cambridge University Press, Cambridge.

Daba, A. S., Youssef, G. A., Kabeil, S. S., \& Hafez, E. E. (2011). Production of recombinant cellulase enzyme from Pleurotus ostreatus (Jacq.) P. Kumm.(type NRRL-0366). African Journal of Microbiology Research, 5(10), 1197-1202.

Djulardi, A. (1995). Respons burung puyuh petelur (Coturnix-coturnix japonica) terhadap pemberian ransum dengan berbagai kandungan fosfor dan imbangan energi-protein. Disertasi. Pascasarjana Universitas Padjadjaran, Bandung.
Fauzi, Y., Widyastuti, Y. E., Satyawibawa, I., \& Paeru, R. H. (2012). Kelapa sawit. Penebar Swadaya Grup.

Haddadin, M. S. Y., Abdulrahim, S. M., Hashlamoun, E. A. R., \& Robinson, R. K. (1996). The effect of Lactobacillus acidophilus on the production and chemical composition of hen's eggs. Poultry science, 75(4), 491-494.

Hatakka, A. (2001). Biodegradation of lignin In: Hofrichter M, Steinbüchel A, editors. Biopolymers 1. Lignin, humic substances and coal.

Howard, G., Pedley, S., Barrett, M., Nalubega, M., \& Johal, K. (2003). Risk factors contributing to microbiological contamination of shallow groundwater in Kampala, Uganda. Water research, 37(14), 3421-3429.

Kirk, T. K., \& Farrell, R. L. (1987). Enzymatic" combustion": the microbial degradation of lignin. Annual Reviews in Microbiology, 41(1), 465-501.

Murugesan, G. S., Sathishkumar, M., \& Swaminathan, K. (2005). Supplementation of waste tea fungal biomass as a dietary ingredient for broiler chicks. Bioresource technology, 96(16), 1743-1748.

Noferdiman, N., \& Yani, A. (2013). Kandungan Nutrisi Lumpur Sawit Hasil Fermentasi dengan Jamur P. chrysosporium. Jurnal Agripet, 13(2), 47-52.

Nuraini, A. D., \& Trisna, A. (2017). Research article palm oil sludge fermented by using Lignocellulolytic fungi as poultry diet. International Journal of Poultry Science, 16(1), 6-10.

Nuraini, A. D., \& Mahata, M. E. (2015). Pakan non konvensional fermentasi untuk unggas.

Rasyaf, M. (1992). Produksi \& pemberian ransum unggas. Penerbit Kanisius.

Sinurat, A. P., Bintang, I. A. K., Purwadaria, T., \& Pasaribu, T. (2001). Pemanfaatan lumpur sawit untuk ransum unggas: 2. Lumpur sawit kering dan produk fermentasi sebagai bahan pakan itik jantan yang sedang tumbuh. Jurnal Ilmu Ternak dan Veteriner, 6(1).

Sinurat, A. P. (2003). Pemanfaatan lumpur sawit untuk bahan pakan unggas. Wartazoa, 13(2), 39-47.

Steel, R. G. D., \& Torrie, J. H. (1995). Prinsip dan prosedur statistika (Terjemahan). Sumantri. PT. Gramedia Pustaka Utama, Jakarta.

Sun, Y., \& Cheng, J. (2002). Hydrolysis of lignocellulosic materials for ethanol production: a review. Bioresource technology, 83(1), 1-11.

Tien, M., \& Kirk, T. K. (1984). Lignin-degrading enzyme from Phanerochaete chrysosporium: purification, characterization, and catalytic properties of a unique $\mathrm{H} 2 \mathrm{O} 2$-requiring oxygenase. Proceedings of the National Academy of Sciences, 81(8), 2280-2284.cfv 